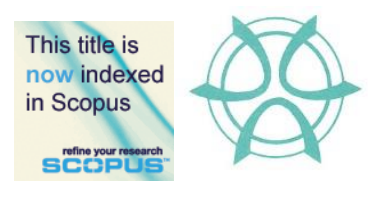

PLANNING MALAYSIA:

Journal of the Malaysian Institute of Planners

VOLUME 15 ISSUE 4 (2017), Page 79 - 90

\title{
THE TRANSFORMATION OF THE MONOCULTURE SYSTEM TOWARDS SUSTAINABLE FARMING PRACTICES AMONG MALAY SMALLHOLDINGS IN KLUANG, JOHOR
}

\author{
Nor Zalina Harun' ${ }^{1}, \&$ Anizah Mohd Salleh ${ }^{2}$ \\ ${ }^{1}$ Institute of Malay World and Civilization \\ UNIVERSITI KEBANGSAAN MALAYSIA \\ ${ }^{2}$ Department of Landscape Architecture \\ UNIVERSITI PENDIDIKAN SULTAN IDRIS
}

\begin{abstract}
Malaysia is known as the largest exporter and second largest producer of world palm oil market. Despite such contributions, a huge amount of forest land has been supplanted by oil palm cultivation. This activity is considered as a major driver of deforestation, which contributes to three-quarters of tropical deforestation globally. Critiques suggest agroforestry systems as option to overcome the issues brought up by the monoculture system of oil palm cultivation. This study is directed to study plant composition and arrangement for agroforestry systems in oil palm smallholdings. Data were gathered using a qualitative approach involving 10 biggest oil palm Malay smallholdings at Kluang, Johor. The study reveals that arrangement involves triangular, double avenue, and boundary planting systems. Further analysis traced that these plant species and arrangement can be categorized into two main categories which are: (i) sustainable plant composition and arrangement, and (ii) unsustainable into sustainable plant composition and arrangement. The study concluded that the transformation of the monoculture system with low sustainability towards more sustainable farming practices of agroforestry systems can actually be achieved through five considerations identified as (i) crop component (ii) maturity of oil palm (iii) market values and demand (iv) belowground and aboveground interaction, and (v) diversification of plant composition and arrangement.
\end{abstract}

Keywords: agroforestry, smallholdings, oil palm cultivation, sustainable agriculture

Date Received: $18^{\text {th }}$ July 2017

Date of Acceptance: $6^{\text {th }}$ November 2017 
Nor Zalina Harun, \& Anizah Mohd Salleh

The Transformation of the Monoculture System Towards Sustainable Farming Practices Among Malay Smallholdings in

Kluang, Johor

\section{INTRODUCTION}

It is reported that food sufficiency, environmental stewardship, and socioeconomic viability and equity are the major paradigms of sustainable agriculture development (Devendra, 2011). Sustainable agriculture is a multidimensional concept considering the environmental or ecological, social, and economic dimensions (Suryanto \& Susila Putra, 2012). Environmental aspects focus on the plant development, including plant growth and its management, which are affected by the agronomic study of soil, water, and crops (Smit \& Smithers, 1993). From an economic perspective, the importance of sustainable agriculture is seen in its sufficient economic returns as an enterprise at the farm level, and a vital economic sector at the regional and national levels. The sector contributes a large amount in the national gross domestic product (GDP) (Dahlan \& Kamal Hisyam, 2014).

It has been reported that $50 \%$ of 4 billion poor rural people depending largely on the crops and livestock production in order to sustain their basic quality of life (Dahlan \& Kamal Hisyam, 2014; Devendra, 2011). Furthermore, it has been reported that the average income of Indonesian smallholder oil palm farmers was seven times higher than subsistence farmers (Wong \& Moog, 2001), but vice versa to Malaysian smallholder farmers (Faridah, 2001). In overall, Malaysian and Indonesian smallholder farmers contribute 35 to $40 \%$ of the whole oil palm production. Based on the situation, Malaysian smallholder farmers need to have initiatives to gain proper technical skill to become skilled and trained farmers. However, without giving and exposing appropriate knowledge and institutional support to the smallholder farmers, they are unable to perform good and sustainable agriculture practices in terms of farming techniques and strategies. These efforts have further improved their land use management in terms of appropriate planning and design of farming practices, suitable selection of composition and arrangement of agroforestry components, and produce continues self-sufficiency products. Taking into such circumstances this study therefore examines the implementation of agroforestry systems as sustainable agriculture practices in oil palm cultivation among smallholdings. The study concerns about how the plant composition and arrangement of agroforestry systems provide positive and neutral benefits to oil palm growers and the surroundings.

\section{LITERATURE REVIEW}

Agroforestry system has been seen as the approach in sustainable agriculture practices that consider the principles of sustainability. It is defined as a dynamic and harmonious solution of natural resources management with the efforts to integrate trees and animals in farming system (Suryanto \& Susila Putra, 2012). The purpose is to increase environmental, social, and economic benefits for both agriculture and forestry sectors. In addition, agroforestry system is also known as a practice of growing crops, trees, and animals in the same unit of agricultural 
PLANNING MALAYSIA

land in accordance to the principles of sustainability. It becomes dynamic systems in which the joint application of agricultural crops, plant, and animal species is able to improve the effectiveness of natural resource usage, increase job opportunities and income, as well as an increase pragmatic production system (Devendra, 2011).

Agroforestry system is also an attempt to overcome the negative effects of the oil palm monoculture development in the agriculture sector. The system is seen as sustainable form of land use option which have the capability to improve the productivity and well-being of rural community (Faridah, 2001; Ahmad Fauzi \& Huda Farhana, 2006; Nurul Ain et al., 2011). Most importantly, the system enables oil palm farmers to maximize the utilization of agricultural land in a sustainable way. Therefore, for this research, agroforestry system refer to various types of farming practice concerning the composition and arrangement of the components that involve in the system. The system must be systematically planned and designed in order to be adopted as a mechanism in planning good agricultural practices (GAP) (Faridah, 2001; Ahmad Fauzi \& Huda Farhana, 2006; Dahlan \& Kamal Hisyam, 2014; Devendra, 2011).

Generally, the evolution of agroforestry system started in Europe, America, Africa, and Asia through shifting cultivation, intercropping, and mixed farming practices (Conklin, 1957; Zeleza, 1993). The system was first implemented in Malaysia through taungya method or intercropping in 1950 (Ahmad Fauzi \& Huda Farhana, 2006). It involved a combination of agricultural and forestry components of agricultural crops, plant, and livestock species. As the knowledge developed, these farming practices were improved by considering the environmental, social, and economic aspects thus known as agroforestry system.

The implementation of agroforestry system within oil palm cultivation by the Malay smallholding farmers often involve integration of oil palm crops with livestock, although mostly cattle instead of goat, buffalo, and poultry. This integration is known as a silvopastoral sub-system, and is popular in Malaysia due to the reduced availability of arable land, as well as rapid demand for animal protein production including meat and dairy products (Dahlan \& Kamal Hisyam, 2014; Devendra, 2011).

In contrast, studies that analysed the integration between oil palm crops and other plant species, or known as agrisilviculture sub-system, are only slightly developed and undervalued its potential, especially towards the environment. As mentioned by Devendra (2011), the initial focus of sustainable agriculture is on environmental aspects. However, it has expanded into broader socioeconomic and political aspects more than the environmental aspects. As the knowledge on sustainability has been spreading in all sectors, it is important to draw attention on the environment, social, and economic benefits of agroforestry system especially with the integration of oil palm crops and other plant species. 
Nor Zalina Harun, \& Anizah Mohd Salleh

The Transformation of the Monoculture System Towards Sustainable Farming Practices Among Malay Smallholdings in

Kluang, Johor

Table 1 shows that earlier studies on agroforestry were mostly focused on the socioeconomic benefits such as increase yield production, additional income for the farmers, and decline cost of weeding and herbicides instead of environmental benefits. Studies on environmental benefits of agroforestry has only increased in the early 2010 , especially those conducted by governmental sector including Malaysian Palm Oil Board (MPOB), Sabah Forestry Department, and Forest Research Institute Malaysia (FRIM). Consideration on three aspects of environment, social, and economic benefits is further developed in more recent studies.

Table 1 Studies on the benefits of agroforestry systems in oil palm cultivation in Malaysia

\begin{tabular}{|c|c|c|c|}
\hline Year & Author & Concern of study & Benefit \\
\hline 2000 & $\begin{array}{l}\text { Rosli } \\
\text { Awaludin }\end{array}$ & $\begin{array}{l}\text { Agrosilvopastoral sub- } \\
\text { system: } \\
\text { Oil palm - cattle (portable } \\
\text { electric fence) }\end{array}$ & $\begin{array}{l}\text { Save cost of weed control } \\
\text { and reduce labor required } \\
\text { for maintenance works }\end{array}$ \\
\hline 2003 & $\begin{array}{l}\text { Rosli } \\
\text { Awaludin \& } \\
\text { Shariffhuddin }\end{array}$ & $\begin{array}{l}\text { Agrosilvopastoral sub- } \\
\text { system: } \\
\text { Oil palm - cattle }\end{array}$ & $\begin{array}{l}\text { Save cost for weed control, } \\
\text { reduce labor required for } \\
\text { maintenance works and } \\
\text { increase cattle production } \\
\text { for food supply }\end{array}$ \\
\hline 2005 & Lee et al. & $\begin{array}{l}\text { Agrisilviculture sub-system: } \\
\text { Oil palm - laran } \\
\text { (Neolamarckia cadamba) } \\
\text { Oil palm - binuang } \\
(\text { Octomeles sumatrana })\end{array}$ & $\begin{array}{l}\text { Supply good quality logs } \\
\text { for the timber industry with } \\
\text { a very high price for per } \\
\text { unit of biomass and the } \\
\text { species are less labour- } \\
\text { intensive that can reduce } \\
\text { the reliance on foreign } \\
\text { labor }\end{array}$ \\
\hline 2006 & $\begin{array}{l}\text { Ahmad Fauzi } \\
\text { \& Huda } \\
\text { Farhana }\end{array}$ & $\begin{array}{l}\text { Agrisilviculture sub-system: } \\
\text { Oil palm - banana (Musa } \\
\text { spp.) } \\
\text { Oil palm - sentang } \\
(\text { Azadirachta excelsa) } \\
\end{array}$ & $\begin{array}{l}\text { Increase production cost } \\
\text { and gross income }\end{array}$ \\
\hline 2008 & $\begin{array}{l}\text { Ahmed Azhar } \\
\text { et al. }\end{array}$ & $\begin{array}{l}\text { Agrisilviculture sub-system: } \\
\text { Oil palm - sentang } \\
\text { (Azadirachta excelsa) } \\
\text { Oil palm - teak (Tectona } \\
\text { grandis) }\end{array}$ & $\begin{array}{l}\text { Increase smallholder } \\
\text { farmers' income }\end{array}$ \\
\hline 2008 & $\begin{array}{l}\text { Tapsir Serin } \\
\text { et al. }\end{array}$ & $\begin{array}{l}\text { Agrosilvopastoral sub- } \\
\text { system: } \\
\text { Oil palm - cattle }\end{array}$ & $\begin{array}{l}\text { Improvement } \\
\text { productivity and efficiency } \\
\text { of beef cattle production } \\
\text { through farmers' skill and } \\
\text { land use management }\end{array}$ \\
\hline 2009 & $\begin{array}{l}\text { Norkaspi } \\
\text { Khasim et al. }\end{array}$ & $\begin{array}{l}\text { Agrisilviculture sub-system: } \\
\text { Oil palm - tongkat Ali } \\
\text { (Eurycoma longifolia) }\end{array}$ & $\begin{array}{lcr}\text { Increase } & \text { in } & \text { land } \\
\text { productivity } & \text { and } & \text { generate } \\
\text { additional } & & \text { income, }\end{array}$ \\
\hline
\end{tabular}


PLANNING MALAYSIA

Journal of the Malaysia Institute of Planners (2017)

\begin{tabular}{|c|c|c|c|}
\hline & & & $\begin{array}{l}\text { especially during the } \\
\text { immature phase }\end{array}$ \\
\hline 2012 & $\begin{array}{l}\text { Hasnol } \\
\text { Othman, } \\
\text { Farawahida, } \\
\text { \& Zulkifli } \\
\text { Hashim }\end{array}$ & $\begin{array}{l}\text { Agrisilviculture sub-system: } \\
\text { Oil palm - Mucuna bracteata }\end{array}$ & $\begin{array}{l}\text { Improve soil fertility, palm } \\
\text { growth, and lower } \\
\text { immaturity phase }\end{array}$ \\
\hline 2014 & $\begin{array}{l}\text { Dahlan Ismail } \\
\text { \& Kamal } \\
\text { Hisyam }\end{array}$ & $\begin{array}{l}\text { Agrosilvopastoral sub- } \\
\text { system: } \\
\text { Oil palm - cattle }\end{array}$ & $\begin{array}{l}\text { Increase family income and } \\
\text { standard of living, improve } \\
\text { crops and cattle production } \\
\text { through centralization of } \\
\text { cooperative marketing and } \\
\text { management system, and } \\
\text { improve the soil fertility via } \\
\text { decomposition of dung and } \\
\text { urine from cattle }\end{array}$ \\
\hline
\end{tabular}

Recently, with the increasing concern for sustainable oil palm production, the significance of agroforestry system has increased. As a result, a monoculture system for oil palm cultivation, formerly known as the most important agricultural activity that contributes to the main agricultural sector of GDP (Kushairi, Azman \& Esnan, 2009) has changed into a more diverse oil palm farming practices of agroforestry system, especially among smallholdings (Devendra, 2011). This tendency towards commercialization of agricultural sustainability was supported by various kinds of subsidy schemes provided by the Department of Agriculture since 2001.

\section{METHODOLOGY}

This study applied exploratory research that employed qualitative research approach. It is to provide a better understanding on how two or more variables are related each other in a situation through the application of inductive reasoning based on empirical evidence through site study. In this research, exploratory was utilized for three purposes; to clarify any intrusiveness of the study for better understanding, to test the feasibility of the study, and to develop the methods to be implemented in other range of study. In addition, Elijido-Ten (2007) also identifies other purposes of exploratory research, which are to observe patterns, ideas, or propositions of the study. It was also decided that exploratory research suggests inductive reasoning.

For the purpose of this study, constructive learning was applied to explore the experiential knowledge, understanding, and awareness on the plant composition and arrangement of oil palm crops and plant species, which is also known as agrisilviculture sub-system. It covers various sources of documentations that are discovered and adapted to fit the knowledge with the scope of this study. Attempt to discover the knowledge also involved social 
Nor Zalina Harun, \& Anizah Mohd Salleh

The Transformation of the Monoculture System Towards Sustainable Farming Practices Among Malay Smallholdings in

Kluang, Johor

interaction with many experts in different specialization in agriculture field, as well as a participants, in this case, the smallholding farmers. Hence, the strategy of inquiry in this study involved the participation and response of smallholding farmers in the selected study area, as well as experts in agriculture field on their experience with agroforestry system. Hence, this study involved in-depth exploration of a process by employing observation, interview, and document analysis as methods of data collection to facilitate the specific direction of the research design.

\section{Study Area}

This study was conducted in Kluang district in Johor, Malaysia, but focusing in Paloh Township. The district is located in the middle of Johor state. In 2010, its population was at 288,364 population, mostly Malay $(138,223)$, and Chinese $(86,690)$ and Indians $(24,102)$ (Department of Statistic Malaysia, 2010). Except for oil palm cultivation in Kluang, the study area consists of a huge number of smallholding farmers. The latest data showed Kluang as the highest district of oil palm smallholdings with the total area of 46,515 hectares being cultivated by 13,053 smallholder farmers. Meanwhile, the selection of Paloh Township as a focus of study is subject to the suggestion by the MPOB officer as the oil palm smallholdings are continuously applied agroforestry system and among the most successful smallholding farmers in Kluang.

\section{Data Analysis}

The data collected were analysed using thematic analysis by conducting different process of qualitative data analysis (QDA) to understand, represent, and formulate an interpretation on the better meaning of the data (Creswell, 2003). The process involves documentation, categorization, connection, corroboration, and representation of the data throughout the study (Schutt, 2012). Hence, the examination of the data analysis for this study includes documentation, conceptualization, coding, and categorizing; examining relationship and displaying data; and triangulation.

\section{FINDINGS AND DISCUSSIONS}

\section{Agroforestry systems as sustainable agriculture practices in oil palm smallholdings}

The findings from the study reveal that transforming agriculture practices into a sustainable one begins with the planning stage. A dynamic interaction from the combination of agriculture and forestry activities is emphasized through agricultural landscape planning and design. The initiatives that consider productivity, sustainability, and adoptability are based on a greater structural and functional complexity of the plant composition and arrangement of the systems. 
PLANNING MALAYSIA

Journal of the Malaysia Institute of Planners (2017)

It refers to the systematic composition and arrangement by getting the right number of oil palm crops and plant species, the right species of plant to be integrated within oil palm smallholdings, and the right arrangement to integrate oil palm crops and plant species in an agricultural land.

Agroforestry planning and design, which involves the consideration of composition and arrangement, is both an artful science of sustainable agriculture development. This consideration is based on the notion that agroforestry system integrates belowground and aboveground interaction that involves perennial crops, annual crops, leguminous cover crops, and grasses. The positive and neutral interactions that contribute to the suitability of the system involve mutualism, facilitation, commensalism, and neutralism interactions. Numerous and diverse plant composition can be found in each level of stratification, partly because of its environmental benefits and the socioeconomic factors such as food and income production. Unlike monoculture system, the integration of agroforestry system ranges from a simple to complex systems with many layers of plant composition.

The diversity and profitability of agroforestry potentially make it as an alternative farming system that is locally acceptable by smallholding farmers. It further creates a sustainable agricultural practices based on the principles of sustainability involving environment, social, and economic aspects. The diversification of plant composition and arrangement has significantly generated profit and economic return to the smallholding farmers either for self-sufficiency or commercial purposes.

The findings gathered from the interview with experts and smallholders, as demonstrated in Figure 1, show how the output return of agroforestry system can be reasonably generated in a short period. These circumstances indeed have resulted in a systematic concept for agroforestry system where the revenue of agroforestry system can be gained in the short or long period depending on the selection of plant composition and arrangement. As a result, currently agroforestry system has become a more important farming system among the smallholding farmers subjected to its ability for rural environment improvement based on its reasonable short period for economic return. 
Nor Zalina Harun, \& Anizah Mohd Salleh

The Transformation of the Monoculture System Towards Sustainable Farming Practices Among Malay Smallholdings in Kluang, Johor

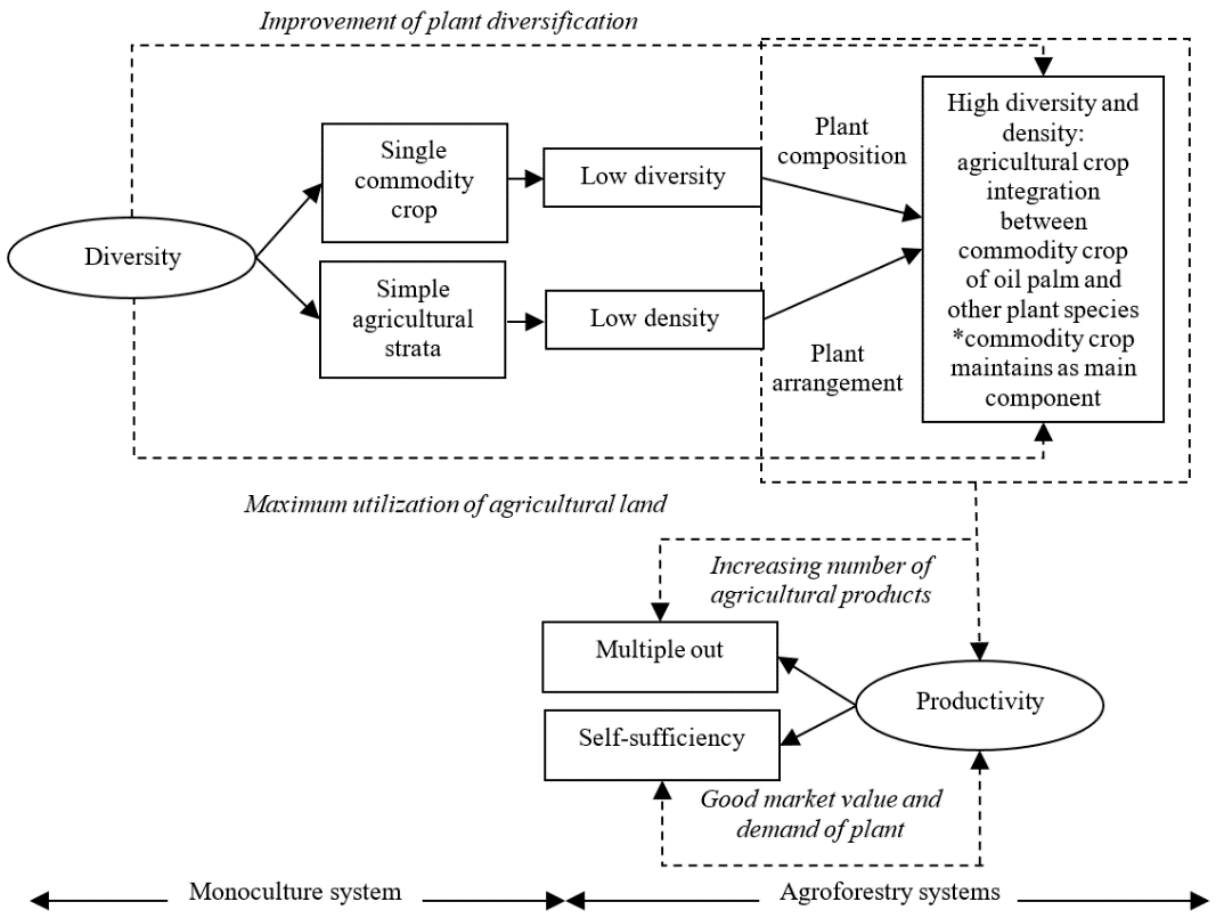

Figure 1 The process of creating sustainable agriculture practices for oil palm smallholdings through agroforestry systems

\section{Plant composition and arrangement of agroforestry system for a sustainable oil palm smallholdings}

In terms of plant arrangement, normally one to three short-term perennial crops is integrated with 2 life cycles in oil palm smallholdings to optimize crop productivity and enhance the environmental conditions. Smallholding farmers are more interested to concentrate on one or two crop production by ensuring a good quality of the product instead of cultivating many crops in the same land. In parallel, the integration of more than two plant species in oil palm smallholdings was only among the same plant family but different species of banana. The plant arrangement that involved in agroforestry system is the process of cultivating a series of different belowground plant composition over time. Compared to monoculture system, belowground integration of plant species was systematically integrated using triangular and double avenue planting systems instead of boundary planting system.

Meeting the needs of a continuous source of income for smallholding farmers will require the integration of various plant species. Currently based on the findings of this study, the oil palm smallholdings are integrated with 10 plant species with the implementation of triangular, double avenue, and boundary 
PLANNING MALAYSIA

Journal of the Malaysia Institute of Planners (2017)

planting systems. The integration was done either during immature phase only or both during immature and mature phase of the oil palm trees. The triangular planting system offered the most suitable plant arrangement for oil palm smallholdings by referring to the total land area owned by the farmers. Here, the range of land area of 1 to 4 hectares for each oil palm smallholdings limits the planning for double avenue planting system. This implies that the implementation of agroforestry system in oil palm smallholdings is on the right track, using the definition of an agrisilviculture sub-system. It implies that the integration of plant species with oil palm crops in the same unit of agricultural land was implemented as the secondary components by focusing on the oil palm production as the main crop productivity.

The most preferred plant composition and arrangement for oil palm smallholdings is the integration of banana species with the triangular planting system. There are five banana species of pisang berangan (Musa acuminata 'Dwarf Cavendish'), pisang tanduk (Musa parasidiaca), pisang susu (Musa sapientum fixa lacte), pisang emas (Musa acuminata 'Lady Finger'), and pisang rastali (Musa sapientum Cv Rastali), which is eventually preferred as the most species integrated by smallholder farmers. The integration also becomes financially sustainable as an alternative source of income for smallholding farmers during the immature or unproductive phases of oil palm crops.

As a whole, the agricultural sustainability of agroforestry systems for oil palm cultivation is influenced by 5 factors as follows (Figure 2):

i. Oil palm crops as main component: oil palm crops considered as central crop production and other plant species as alternative crop production.

ii. Maturity of oil palm crops: the suitability of plant composition and arrangement depends on the oil palm age that involving the immature and mature phase of oil palm crops.

iii. Belowground and aboveground interaction: agroforestry systems produce positive or neutral interaction between oil palm crops and other plant species which involving mutualism, facilitation, commensalism, and neutralism interaction.

iv. Agricultural landscape planning and design: integration is not decreasing the oil palm growth performance through appropriate management of plant composition and arrangement.

v. Market values and demand: farmers' interest in selecting profitable plant species 
Nor Zalina Harun, \& Anizah Mohd Salleh

The Transformation of the Monoculture System Towards Sustainable Farming Practices Among Malay Smallholdings in Kluang, Johor

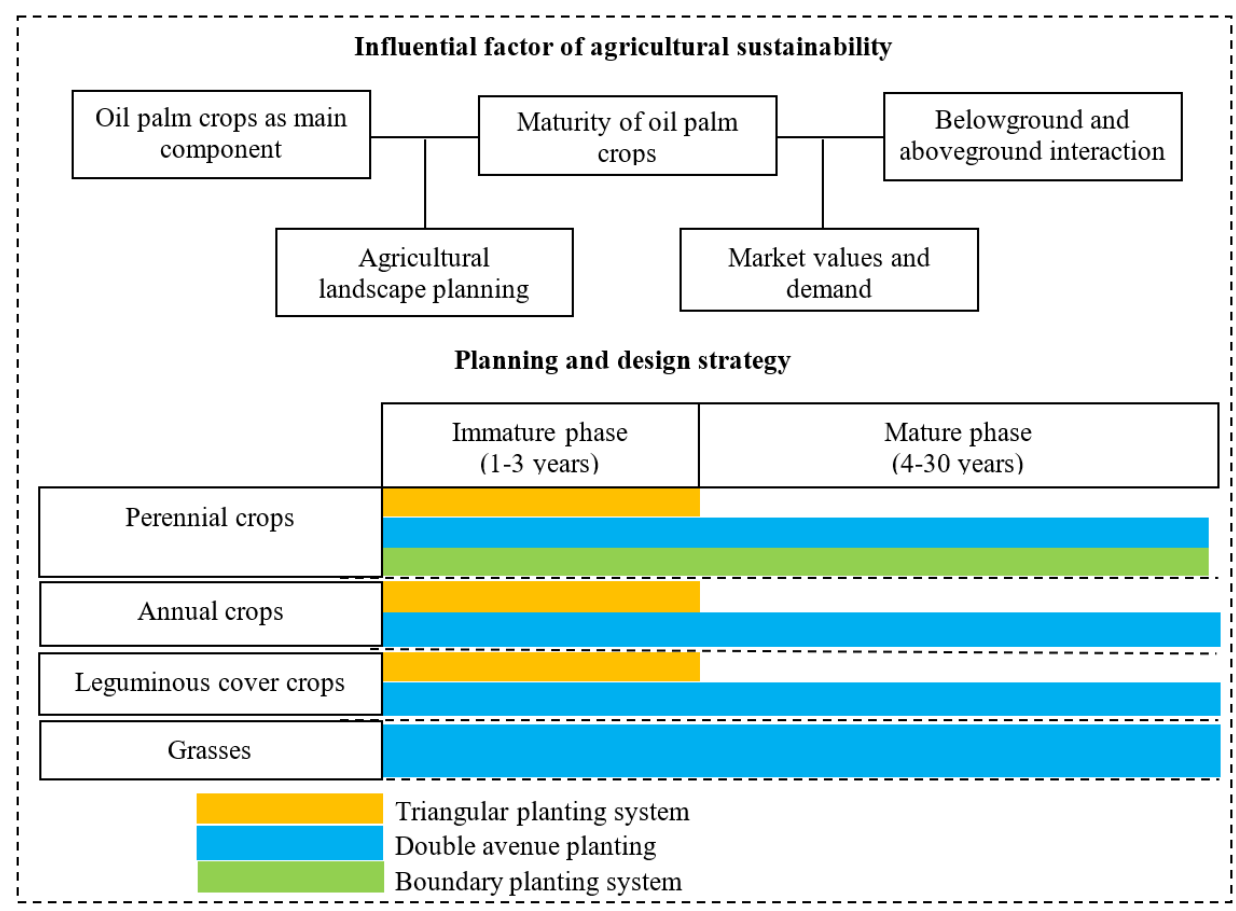

Figure 2 Influential factor of agriculture sustainability

\section{CONCLUSION}

Agroforestry system is a new name of old agricultural practices which includes shifting cultivation, intercropping, and mixed farming. The term is derived from a combination of agriculture and forestry activities and involved multiplicity of environment, social, and economic interaction. This interaction makes people recognize agroforestry systems as an approach in creating sustainable agriculture practices. In terms of oil palm smallholdings, rapid development and expansion of natural forest into oil palm land has decreased the agricultural sustainability of Malaysian oil palm production. In this study, it shows that diverse plant species can be integrated with oil palm crops in creating and balancing the sustainable agriculture land. The detailed examination indeed has highlighted that only certain types of plant species were chosen by the smallholder farmers as their alternative crops. As a whole, their selection was influenced by the reflection of oil palm crops as main crop production, agricultural landscape planning and design, and comparative advantages concept of the alternative crops.

In broader aspect, as plant species being integrated within the area of oil palm crops, the revenue obtained is socially alleviating poverty among the rural smallholding farmers. It is expected that implementation of agroforestry system in oil palm smallholdings is considered as a potential sustainable approach to create a better environmental and socioeconomic values. Therefore, it is vitally 
important for agriculturists, planners, and farmers to plan and design suitable plant composition and arrangement in order to create sustainable agriculture land use system. Likewise, enhancing the positive values and avoiding negative values with the proper planning and farming system may present an environmentally friendly, socially capable, and economically viable sustainable agriculture practice.

\section{REFERENCES}

Ahmad Fauzi Puasa, \& Huda Farhana Mohammad Muslim. (2006). The study of several agroforestry systems and land used options in Malaysia. In International Agroforestry Conference 2006: Harnessing the Benefits.

Ahmed Azhar Jaafar, Norman Kasiran, Suhaimi Muhammed, \& Wan Hanisah Wan Ismail. (2008). Agroforestry practices in Malaysia - Integrating plantations crops with timber species. In International Plantation Industry Conference \& Exhibition. Retrieved from http://www.ipicex.com/docs/posters/Ahmed Azhar et al.pdf

Conklin, H. C. (1957). Hanunoo agriculture. Unasylva, 11(4). Retrieved from http://www.fao.org/docrep/x5385e/x5385e05.htm

Creswell, J. W. (2003). Research design: Qualitative, quantitative and mixed method approaches (2nd Ed.). London: SAGE Publication Ltd.

Dahlan Ismail, \& Kamal Hisyam Abdul Wahab. (2014). Sustainability of cattle-crop plantations integrated production systems in Malaysia. International Journal of Development and Sustainability, 3(2), 252-260.

Department of Statistic Malaysia. (2010). Johor-Department of Statistic Malaysia (pp. 231-243). Retrieved from http://www.statistics.gov.my /portal/download_Population/files/population/05Jadual_Mukim_negeri/Mukim Johor.pdf

Devendra, C. (2011). Integrated tree crops-ruminants systems in South East Asia: Advances in productivity enhancement and environmental sustainability. AsianAustralian Journal of Animal Sciences, 24(5), 587-602.

Elijido-Ten, E. (2007). Combining qualitative and quantitative methods in environmental accounting research. In 6th Australasian Conference on Social and Environmental Accounting Research (CSEAR). Sydney, Australia.

Faridah Ahmad. (2001). Sustainable agriculture system in Malaysia. In Regional Workshop on Integrated Plant Nutrition System (pp. 18-20). Bangkok. Retrieved from http://banktani.tripod.com/farid International Agroforestry Conference 2006ah.pdf

Hasnol Othman, Farawahida Mohamad Darus, \& Zulkifli Hashim. (2012, June). Best management practices for oil palm cultivation on peat: Mucuna bracteata as ground cover crop. MPOB Information Series.

Kushairi A., Azman Ismail, \& Esnan Ab Ghani. (2009). Industri sawit di Malaysia. In E. Ab Ghani \& I. Omar (Eds.), Perusahaan Sawit di Malaysia-Satu Panduan. Malaysian Palm Oil Board.

Lee, Y. F., Chia, F. R., Anuar, M., Ong, R. C., \& Ajik, M. (2005). The use of Laran and Binuang for forest plantations and intercropping with oil palm in Sabah. Sepilok Bulletin, 3, 1-13. 
Nor Zalina Harun, \& Anizah Mohd Salleh

The Transformation of the Monoculture System Towards Sustainable Farming Practices Among Malay Smallholdings in

Kluang, Johor

Norkaspi Khasim, Raja Zulkifli Raja Omar, Suboh Ismail, \& Wahid Omar. (2009, June). Integration of tongkat Ali with oil palm. MPOB Information Series.

Nurul Ain Noor Rahman, Mohd Nazip Suratman, Abdul Rasip Abdul Ghani, \& Tsan, F. Y. (2011). Karas (Aquilaria malaccensis) agroforestry system for sustainable land use. In Rehabilitation of Tropical Rainforest Ecosystems (pp. 401-407).

Rosli Awaludin. (2000, August). Systematic integration of cattle in oil palm. MPOB Information Series. Retrieved from http://www.mpob.gov.my /tot/tt96.pdf

Rosli Awaludin, \& Shariffhuddin Hj. Masurni. (2003). Systematic beef cattle integration in oil palm plantation with emphasis on the utilization of undergrowth Lakakarya Sistem Integrasi Kelapa Sawit-Sapi, 23-35.

Schutt, R. K. (2012). Investigating the social world. The process and practice of research (Seventh Ed.). Boston: SAGE Publication Ltd.

Smit, B., \& Smithers, J. (1993). Sustainable agriculture: Interpretations, analyses and prospects. Canadian Journal of Regional Science, XVI(3), 499-524.

Suryanto, P., \& Susila Putra, E. T. (2012). Traditional enrichment planting in agroforestry marginal land Gunung Kidul, Java, Indonesia. Journal of Sustainable Development, 5(2), 77-87.

Tapsir Serin, Alias Radam, Mad Nasir Shamsudin, \& Zainalabidin Mohamed. (2008). The efficiency of beef cattle production: A case study in the target area of concentration in Johor, Malaysia. Economic and Technology Management Review, 3, 57-74.

Wong, C. C., \& Moog, F. A. (2001). Forage, livestock and tree crop integration in Southeast Asia: Present position and future prospects. In 7th Meeting of the Regional Working Group on Grazing and Feed Resources. Indonesia. Retrieved from http://www.fao.org/ag/agp/agpc/doc/ proceedings/manado/chap1.htm

Zeleza, T. (1993). A modern economic history of Africa. Nairobi: East African Educational Publishers Ltd. 